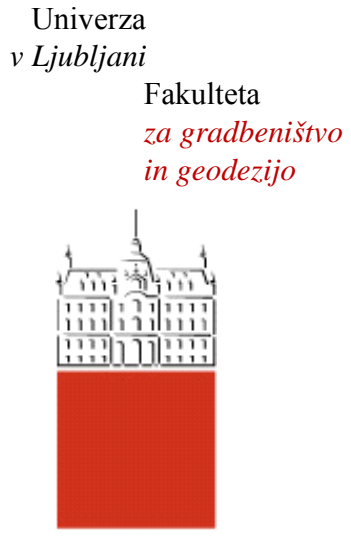

Jamova cesta 2 1000 Ljubljana, Slovenija http://www3.fgg.uni-lj.si/

\section{DRUGG - Digitalni repozitorij UL FGG http://drugg.fgg.uni-lj.si/}

V zbirki je izvirna različica izdajatelja.

Prosimo, da se pri navajanju sklicujete na bibliografske podatke, kot je navedeno:

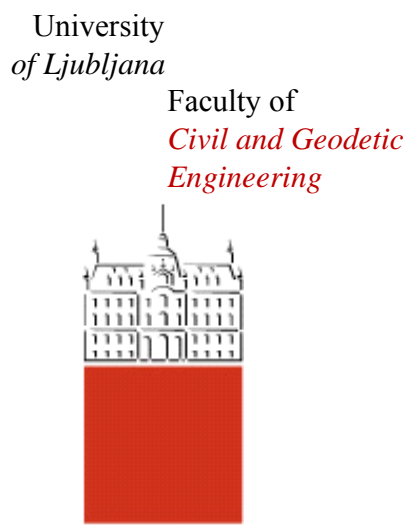

Jamova cesta 2 SI - 1000 Ljubljana, Slovenia http://www3.fgg.uni-lj.si/en/ DRUGG - The Digital Repository
http://drugg.fgg.uni-lj.si//

This is a publisher's version PDF file.

When citing, please refer to the publisher's bibliographic information as follows:

Obučina, M., Turk, G., Džaferović, E., Resnik J. 2013 Influence of gluing technology on physical and mechanical properties of laminated veneer lumber. Drvna industrija 64, 1: 3338. doi: $10.5552 /$ drind.2013.1114. 


\title{
Influence of Gluing Technology on Physical and Mechanical Properties of Laminated Veneer Lumber
}

\section{Utjecaj tehnologije lijepljenja na fizikalna i mehanička svojstva lamelirane drvne građe}

\author{
Original scientific paper • Izvorni znanstveni rad \\ Received-prispjelo: 6. 4. 2011. \\ Accepted-prihvaćeno: 15. 11. 2012. \\ UDK: $630 * 812 ; 630 * 824.3 ; 674-419.32$ \\ doi:10.5552/drind.2013.1114
}

\begin{abstract}
This paper presents the analysis of the influence of conventional hot (CH) and high frequency $(\mathrm{HF})$ gluing on relevant physical and mechanical properties of Laminated Veneer Lumber (LVL) made from beech peeled veneer with the thickness of $2.1 \mathrm{~mm}$. Student's T-test was applied to determine the significance of differences between mean values of results obtained for the two different treatments. A significant difference has been determined for the thickness loss, density, moisture and bending strength, while no statistically significant difference has been established for the modulus of elasticity and shear strength of gluing between the means of the tested samples.
\end{abstract}

Key words: laminated veneer lumber, hot gluing, high frequency gluing, physical properties, mechanical properties

SAŽETAK • U radu je istraživan utjecaj klasičnoga vrućeg (KV) i visokofrekventnog (VF) lijepljenja na neka relevantna fizikalna i mehanička svojstva uzoraka lamelirane drvne građe (LVL) dobivene od listova ljuštenoga bukova furnira debljine 2,1 mm. Prikazani su i analizirani dobiveni rezultati. Primijenjen je T-test za određivanje značajnosti razlike artimetičkih sredina dvaju skupova uzoraka. Za smanjenje debljine, gustoću, sadržaj vode i čvrstoću na savijanje utvrđena je signifikantna razlika, a za modul elastičnosti i čvrstoću lijepljenja nije utvrđena signifikantna razlika artimetičkih sredina ispitivanih uzoraka izrađenih primjenom različitih tehnologija lijepljenja.

Ključne riječi: lamelirana drvna građa, klasično vruće lijepljenje, visokofrekventno lijepljenje, fizikalna svojstva, mehanička svojstva

\section{INTRODUCTION 1. UVOD}

In wood industry, gluing is the most commonly used technological procedure for wood bonding. Different heating procedures and wood gluing have been developed recently. Two procedures are the most often applied in industry: indirect (contacting) - conventional hot gluing $(\mathrm{CH})$, direct (dielectric) - high frequency (HF) gluing. The essential differences between $\mathrm{CH}$ and HF gluing are in the type of heating, temperature and moisture gradients and gluing time. The experiment

\footnotetext{
${ }^{1}$ Authors are assistant professor and professor at University of Sarajevo, Mechanical Engineering Faculty, Sarajevo, Bosnia and Herzegovina. ${ }^{2}$ Author is professor at University of Ljubljana, Faculty of Civil and Geodetic Engineering, Ljubljana, Slovenia. ${ }^{3}$ Author is retired professor of University of Ljubljana, Biotechnical Faculty, Ljubljana, Slovenia.

Autori su docent i profesor Strojarskog fakulteta Sveučilišta u Sarajevu, Sarajevo, Bosna i Hercegovina. ${ }^{2}$ Autor je profesor Fakulteta građevine i geodezije Sveučilišta u Ljubljani, Ljubljana, Slovenija. ${ }^{3}$ Autor je umirovljeni profesor Biotehničkog fakulteta Sveučilišta u Ljubljani, Ljubljana, Slovenija.
} 
was performed to analyze relevant physical and mechanical properties of laminated specimens obtained by the two different gluing procedures.

In recent years, the use of laminated elements made of glued sheets of veneer or laminated solid wood has increased considerably. Such laminated elements have good mechanical and rheological properties and better form stability than the products made of one piece of solid wood. Laminated veneer lumber (LVL) is made from peeled veneers of different thickness and types of wood. Veneer sheets are usually equally oriented and they are bonded by waterproof glue. In practice, LVL products are manufactured using conventional $\mathrm{CH}$ gluing and HF gluing. Several experiments have shown that the thickness losses of HF glued products differ more than those manufactured by $\mathrm{CH}$ gluing (Resnik et al. 1994, Resnik et al., 1995). Different thickness losses during $\mathrm{CH}$ and $\mathrm{HF}$ gluing result in different physical and mechanical properties of the LVL, so that such products behave quite differently in climate changes and with long-term use. Armstrong (1982) has shown that the change in moisture by $1 \%$ below the hygroscopic limit affects the change of bending strength by $4 \%$. The change in wood density from $700 \mathrm{~kg} / \mathrm{m}^{3}$ to $800 \mathrm{~kg} / \mathrm{m}^{3}$ has resulted in the increase of the bending strength from $125 \mathrm{~N} / \mathrm{mm}^{2}$ to $135 \mathrm{~N} / \mathrm{mm}^{2}$.

The aim of this paper is to analyze the influences of $\mathrm{CH}$ and $\mathrm{HF}$ gluing on relevant physical and mechanical properties of LVL made from beach peeled veneer.

\section{MATERIALS AND METHODS}

2. MATERIJAL I METODE

First-class peeled beech veneer (Fagus Sylvatica L.), was used to create a sample of LVL specimens. Sheets of the size $550 \mathrm{~mm} \times 550 \mathrm{~mm}$ and thickness of $2.1 \mathrm{~mm}$ were prepared. Moisture content was determined by gravimetric method according to EN 322 and it averaged $5.5 \%$. To minimize the effect of defects of wood structure and different density values on the experiment results, the veneer sheets for the production of LVL specimens were selected and graded. Veneer sheets were visually inspected and sheets without bumps, cracks, curling, and discoloration with more or less the same thickness were selected. The density of each sheet of veneer was calculated, and veneer sheets of approximately the same density were used in the experiment.

Melamine-urea-formaldehyde glue MELDUR H97, produced by Melamin Kočevje, was used for gluing LVL specimens. The glue was prepared according to the manufacturer's recipe. Glue mixture was spread over veneer manually by a roller in the quantity of 180 $\mathrm{g} / \mathrm{m}^{2}$, and the open assembly time was about 5 minutes. The specific gluing pressure was $1.8 \mathrm{MPa}$.

LVL panels were made of seven veneer sheets. LVL test panels were glued together in a hydraulic press, with the possibility of conventional conductive heating and heating in a high frequency electricity field (HF). The surface of press panels was $600 \mathrm{~mm}$ x $600 \mathrm{~mm}$ (Figure 1). The bonding temperature was $125^{\circ} \mathrm{C}$ (as recom-

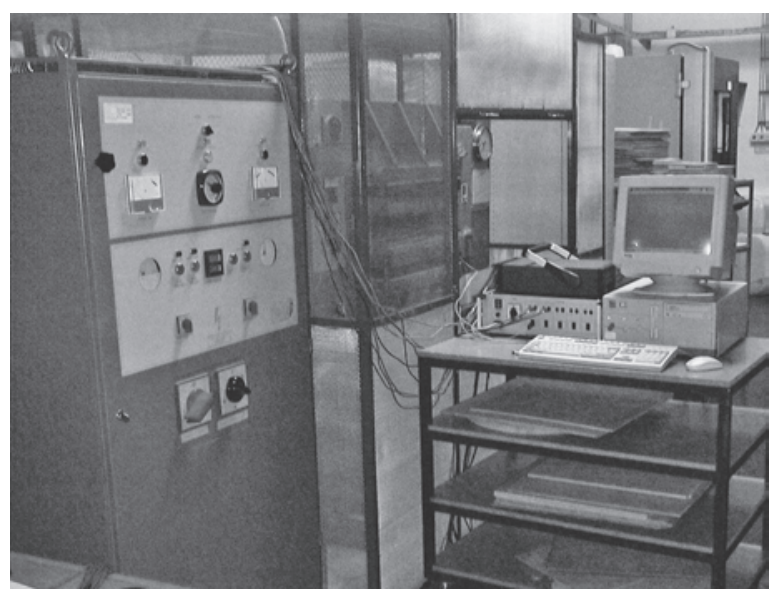

Figure 1 Hydraulic conventional and HF press with a device for measuring temperature

Slika 1. Klasična hidraulična preša i visokofrekventna preša $\mathrm{s}$ uređajem za mjerenje temperature

mended by the glue manufacturer). The time of bonding was determined by measuring the time of reaching the temperature in the middle of the panel, between the $3^{\text {rd }}$ and $4^{\text {th }}$ sheet of veneer. The basic time needed for curing glue was added to the time of bonding.

Temperature changes were measured by thermocouples connected to a digital multi-channel instrument MI 7852 ISKRAAMPER. HF generator was used for HF gluing. The working frequency of the generator was $4.75+0.5 \mathrm{MHz}$, nominal power $6-18 \mathrm{~kW}$ and electrical field between electrodes was $800 \mathrm{~V} / \mathrm{cm}$. The output power of $12 \mathrm{~kW}$ and the power of anode flow current of $1 \mathrm{~A}$ were used.

When the temperature in the middle of the plate reached $125{ }^{\circ} \mathrm{C}$, the generator was switched on and off in equal time intervals. When the generator was switched off, the temperature between the $3^{\text {rd }}$ and $4^{\text {th }}$ sheet of veneer was measured. The diagram flow of the temperature between the $3^{\text {rd }}$ and $4^{\text {th }}$ sheet is shown in Figure 2.

Eight LVL boards have been glued during each gluing procedure using the same gluing pressure of 1.8 $\mathrm{MPa}$ and the same final temperature of $125^{\circ} \mathrm{C}$. Gluing (curing) time in conventional hot procedure was 13 minutes, and in the HF gluing 7 minutes. After the gluing, the panels were conditioned for 48 hours in an airconditioned chamber. Panels obtained by conventional hot glue are marked with $\mathrm{CH}$ and panels obtained by HF bonding are marked with HF.

After the air conditioning in standard climate, standard samples were taken from each plate for the determination of relevant physical and mechanical properties. Then the prepared specimens were returned to the chamber with the standard air conditioning ( $T=$ $20{ }^{\circ} \mathrm{C}$ and $\varphi=65 \%$ ) and held up there until the direct testing.

Some relevant physical and mechanical properties of laminated specimens were determined after standard conditioning according to the corresponding standard methods.

$\rho$ density $\left(\mathrm{kg} / \mathrm{m}^{3}\right)$

EN 322: 1996

$w$ moisture content (\%) $\quad$ EN 323: 1996 
..... Obućina, Goran Turk, Ejub Džaferović, Jože Resnik: Influence of Gluing Technology...

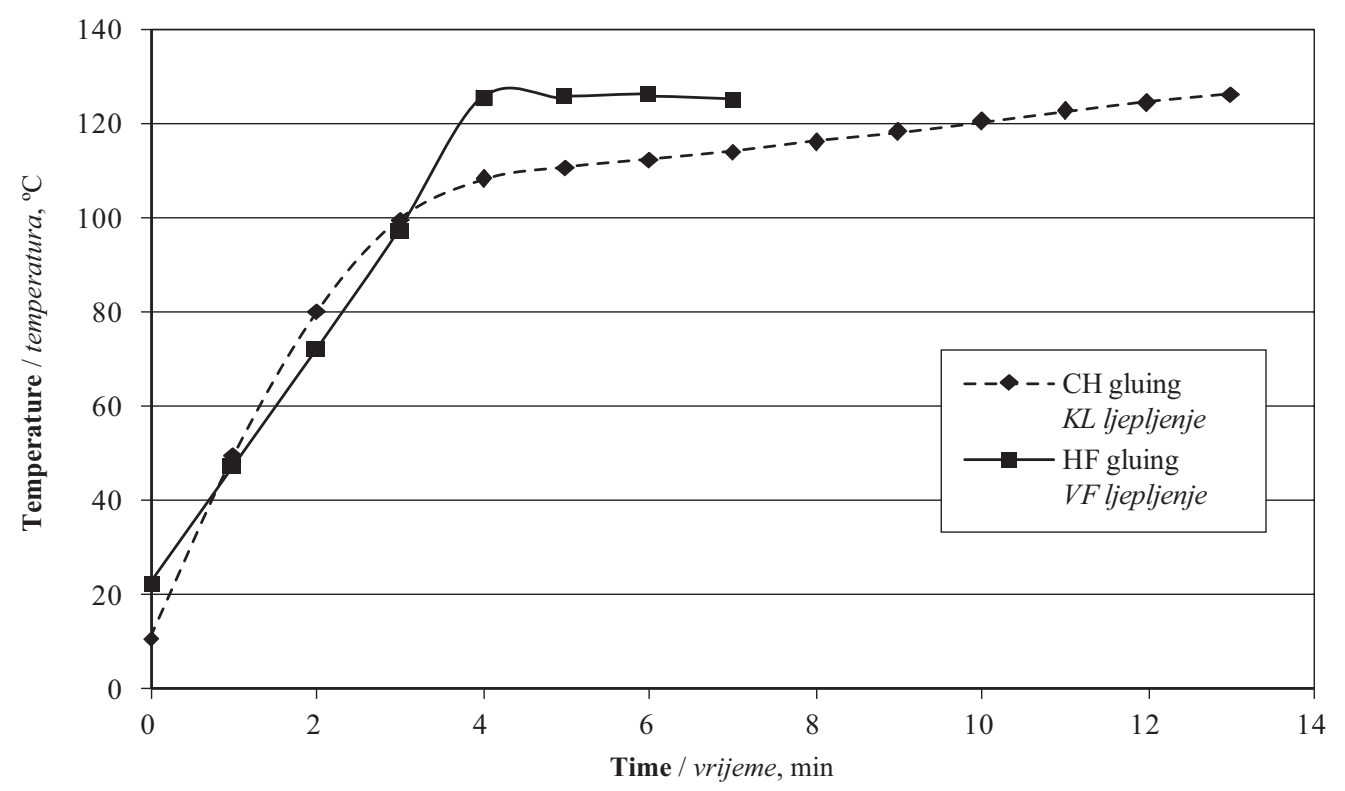

Figure 2 Dependence of temperature in the middle of the specimen on gluing procedure time Slika 2. Ovisnost temperature u središtu uzorka o trajanju procesa lijepljenja

$\sigma_{\text {bs }}$ bending strength $\left(\mathrm{N} / \mathrm{mm}^{2}\right)$

EN 310: 1993

$E_{m}$ modulus of elasticity $\left(\mathrm{N} / \mathrm{mm}^{2}\right)$

$\sigma_{\mathrm{ss}}$ shear strength $\left(\mathrm{N} / \mathrm{mm}^{2}\right)$

$T L$ thickness loss (\%)

Thickness loss $(T L)$ is a deformation that occurs when wood is glued and it results from the pressure and other gluing factors. The size of the deformation in certain types of wood are mostly affected by wood moisture content, temperature of gluing and the time of pressure application during gluing.

Higher thickness loss affects the stresses in the adhesive joint and gives a lower strength and stability of glued joints. Also, thickness loss affects physical and mechanical properties of laminated elements.

Thickness loss was determined twice: immediately after bonding and after conditioning in a standard climate.

Thickness loss is defined by the following equation:

Where:

$$
T L=\frac{\sum_{i=1}^{7} d_{i}-d_{k}}{\sum_{i=1}^{7} d_{i}} \cdot 100 \%
$$

$T L$ - thickness loss / smanjenje debljine (\%),

$\sum_{i=1}^{7} d_{i}-$ the sum of thickness of sheets in the panel be-
fore gluing / zbroj debljine furnirskih listova $u$ ploči prije lijepljenja $(\mathrm{mm})$,

$d_{\mathrm{k}}$-final panel thickness / konačna debljina ploče $(\mathrm{mm})$.

Since MUF glue belongs to the category of waterproof adhesives, we applied two criteria to test its water resistance. In the first case, the specimens were immersed in water with the temperature of $(20 \pm 3){ }^{\circ} \mathrm{C}$ for 24 hours before the testing. The second treatment consisted of cooking in boiling water for 4 hours, then drying at a temperature of $(60 \pm 3){ }^{\circ} \mathrm{C}$ for 16 hours, then again cooking in hot water for 4 hours and cooling in water with the temperature of $(20 \pm 3){ }^{\circ} \mathrm{C}$ for two hours. Then the shear strength was determined. Time to fracture was $30 \pm 5$ seconds. After drying, the percentage of failure at the adhesive or wood was assessed with the accuracy of $5 \%$.

Our specimens consist of seven veneer sheets and the strength is determined by adhesive layer near the middle of the sample, i.e. at the third layer of glue.

\section{RESULTS AND DISCUSSION} 3. REZULTATI I RASPRAVA

Statistical analysis was performed by Student's $T$-test for testing the hypothesis whether the means of the two sets were significantly different. One set consisted of specimens glued by HF method, and the other set of specimens were glued with the standard procedure of $\mathrm{CH}$ gluing. In both cases we had the same number of specimens so that the number of degrees of freedom was

$$
v=n_{H F}+n_{C H}-2
$$

Rejection region was taken with the double $T$ test. Statistics $T$ was calculated in excel by the equation:

Where

$$
T_{\text {test }}=\frac{\bar{X}_{H F}-\bar{X}_{C H}}{S^{*} \sqrt{\frac{1}{n_{H F}}+\frac{1}{n_{C H}}}}
$$

$\bar{X}$ - average / srednja vrijednost,

$n$ - number of specimens / broj uzoraka,

$S^{k^{2}}$ - variance calculated by the equation (4) / varijanca izračunana iz jednadžbe (4)

$$
S^{*^{2}}=\frac{\left(n_{H F}-1\right) S_{H F}^{*^{2}}+\left(n_{C H}-1\right) S_{C H}^{*^{2}}}{n_{H F}+n_{C H}-2}
$$

If $\left|T_{\text {test }}\right| \leq t_{v ; 0.975}$, null hypothesis is not rejected. If $\left|T_{\text {test }}\right|>t_{v ; 0.975}$, null hypothesis is rejected with the risk 
Table 1 Physical and mechanical properties that have shown significant difference established by $T$ test between two methods of gluing

Tablica 1. Fizikalna i mehanička svojstva za koja je T-testom utvrđena signifikantna razlika među skupinama uzoraka lijepljenih dvjema različitim tehnologijama

\begin{tabular}{|l|c|c|c|c|c|}
\hline $\begin{array}{l}\text { Properties } \\
\text { Svojstva }\end{array}$ & $\boldsymbol{H F}$ & $\boldsymbol{C H}$ & $\boldsymbol{v}$ & $\boldsymbol{t}_{\boldsymbol{v} \mathbf{0 . 9 7 5}}$ & $\boldsymbol{T}_{\text {test }}$ \\
\hline$T L, \%$ & 5.4 & 7.1 & 14 & 2.145 & 6.130 \\
\hline$\rho, \mathrm{kg} / \mathrm{m}^{3}$ & 743.69 & 757.27 & 94 & 1.986 & 5.793 \\
\hline$w, \%$ & 9.85 & 9.49 & 94 & 1.986 & 8.487 \\
\hline$\sigma_{b s}, \mathrm{~N} / \mathrm{mm}^{2}$ & 129.9 & 137.8 & 46 & 2.0129 & 2.922 \\
\hline
\end{tabular}

Legend / Legenda: $T L$ - thickness loss / smanjenje debljine; $\rho$ - density / gustoća; $w$ - moisture content / sadržaj vode; $\sigma_{\mathrm{bs}}$ - bending strength / čvrstoća na savijanje

of $5 \%$ and it is said that the difference in means is significant.

Table 1 provides an overview of the results of the studied physical and mechanical properties of the produced LVL where significant difference in mean values was established.

The LVL's thickness loss affects the formation of glued joint, hygroscopic behavior (swelling and shrinkage), density, thermal and electrical properties, as well as the strength of material. Greater loss of thickness causes higher internal stress and lower stability of the glued joint. The average value of thickness loss in the conventional hot gluing of LVL was $7.1 \%$, whereas in HF gluing it was $5.4 \%$, which makes a difference of $1.7 \%$.

Wood is amorphous material (due to the amorphous areas of lignin between the high molecular cellulose), and if exposed to the temperature of $70{ }^{\circ} \mathrm{C}$ and higher, it gets plastically deformed. At this temperature, the cellulose crystal grids oscillate so that the cohesive forces are reduced and mobility of bound water increases.

The viscosity of lignin and pectin decreases; thermally unstable polyoses decompose (Scallan, 1974). Under the influence of external pressure, the inner surfaces get closer and establish new hydrogen relations between hydroxyl groups, which are located on the surface and wall of the cell.

The water content in wood has an important impact on the loss of thickness under pressure. An increase in water content to the hygroscopic limit reduces the temperature of plastification and increases the deformation. The water penetrates between the crystals of cellulose weakening the bond among them. In addition, water dissolves pectic substances and polyoses and thus further weakens the intermolecular connections, which increases the deformation (Gorišek, 1987).

The movements of heat and water in different gluing procedures are different. During hot gluing, the adhesive joint is heated from the outer layers toward the centre. The heat is transferred to the outer layer of wood from the press plates, resulting in more intense heating of layers - glued elements closer to the presser plates. Its intensity decreases with the distance from the presser plates. This gradient in temperature affects the water transfer in the glued specimen.

At a certain temperature and pressure, water turns into steam. In the outer layers the vapor has a higher pressure and temperature with respect to the centre of the glued element. One part of the steam evaporates into the environment, while the other, due to differences in vapor pressures, moves toward the centre of the specimen. When the vapor reaches the layers with lower temperature, it condensates. This results in a gradient of moisture from the centre toward the outer layers. Due to high temperatures in the outer layers, the moisture rapidly decreases, which results in greater plastic deformation in the outer layers than in the inner layers.

In the case of HF gluing, the temperature and moisture distribution is different. The heat is generated inside the material, which results in an almost uniform temperature distribution. Due to different dielectric properties, the wood temperature increases slower than the glue temperature, which is desirable for gluing. A part of the heat from the outer layers is transferred to press plates and the surrounding air. This approximately uniform temperature distribution causes a quick moisture distribution, which becomes uniform as well. Therefore the residual stresses are reduced and the loss of thickness is uniform in the entire cross-section.

The gluing time has an important effect on the loss of thickness. The temperature diagram flow (Fig. 2) shows that the gluing time at the temperatures above $100^{\circ} \mathrm{C}$ is about 10 minutes in the case of conventional gluing, and only 3.5 minutes in the case of HF gluing. This results in greater plastic deformations in conventional gluing than in HF gluing. If during the application of pressure, wood moisture remains approximately the same, and the temperature of wood increases, total thickness loss will depend on the time of exposure to elevated temperature. All other parameters of gluing in the experiment were the same in both cases and could not significantly affect the outcome.

Density of wood is an important physical property of wood. Density of layered glued wood is greater than the density of solid wood with the same moisture content. Nikolić (1988) reports an increase in density of 18 to $20 \%$, Mesić (1998) of 13 to $20 \%$. In our experiment, the density of specimens with HF gluing increased by $4.7 \%$, and with conventional gluing by 6.7 $\%$. A slightly higher density in the case of conventional gluing is the result of a greater loss of thickness.

Density also depends on the moisture content of wood. The HF glued specimens have slightly higher moisture content than the conventionally glued specimens. This is the reason why the difference in density is not higher.

Moisture content below the hygroscopic limits has a significant effect on the mechanical properties of wood. Armstrong (1982) found that the change in moisture content of $1 \%$ causes the change of bending strength (4\%), elastic modulus $(1.5 \%)$ and compressive strength $(5 \%)$.

Laminated glued elements are often loaded by the transverse load, and therefore the bending strength 
Table 2 Mechanical properties for which $T$-test revealed no significant differences

Tablica 2. Mehanička svojstva za koja $T$-testom nije utvrđena signifikantna razlika među skupinama uzoraka lijepljenih dvjema različitim tehnologijama

\begin{tabular}{|l|c|c|c|c|c|}
\hline $\begin{array}{l}\text { Properties } \\
\text { Svojstva }\end{array}$ & HF & CH & $\boldsymbol{v}$ & $\boldsymbol{t}_{\boldsymbol{v} \text { } .975}$ & $\boldsymbol{T}_{\text {test }}$ \\
\hline$E_{m}, \mathrm{~N} / \mathrm{mm}^{2}$ & 13978 & 14015 & 46 & 2.0129 & 0.17 \\
\hline$\sigma_{s t .1}, \mathrm{~N} / \mathrm{mm}^{2}$ & 7.83 & 7.39 & 28 & 2.0484 & 1.0565 \\
\hline$\sigma_{s t .2}, \mathrm{~N} / \mathrm{mm}^{2}$ & 9.85 & 9.49 & 28 & 2.0484 & 1.0048 \\
\hline
\end{tabular}

$E_{m}$ - modulus of elasticity / modul elastičnosti; $\sigma_{\mathrm{ss}-1}-$ shear strength after soaking in water / smicajna čvrstoća nakon namakanja $u$ vodi; $\sigma_{\text {ssi }}$ - shear strength after boiling in water / smicajna čvrstoća nakon kuhanja $\mathrm{u}$ vodi

is the most crucial mechanical property for dimensioning of elements. The average bending strength of LVL glued with conventional procedure was higher by 6.1 $\%$ than LVL glued with HF gluing procedure. The density and moisture content of wood have a major effect on bending strength. The density of conventionally glued specimens was higher by about $1.8 \%$ compared to the density of HF glued specimens. Humidity of the conventionally glued specimens was $3.8 \%$ lower than the HF glued specimens.

Table 2 provides a brief overview of the results of the studied physical and mechanical properties of the LVL samples where no significant difference in mean values was established.

The experiment showed a negligible difference in the elastic modulus $(0.3 \%)$. With respect to higher density and lower moisture of standard glued samples, one would expect a greater difference in elastic modulus.

Bending strength and bond strength of LVL specimens, glued by both procedures, are very high. This shows that the gluing process and selection of veneer sheets were performed correctly, which resulted in a low coefficient of variation for $E_{m}$ in both gluing processes.

For glued structures exposed to changing humidity, the European standard (EN 314-1:1993) requires testing of shear strength in two regimes. The first regime implies soaking in the water at room temperature $(20 \pm 3)^{\circ} \mathrm{C}$, and then testing the shear strength of the glue bond. If the strength is adequate, than the second regime is applied, i.e. cyclic cooking of samples and then testing the shear strength. The shear strength in the middle of the glue bond was higher for HF glued specimens in both regimes $(6.0 \%$ higher in soaking regime and $4.6 \%$ higher in cooking regime).

Rowell (1996) found that the strength of the glue bond depends on many factors, the two most important being the adhesive properties and adhesion. Adhesion of glue-wood primarily depends on surface wetting, glue penetration, porosity, $\mathrm{pH}$, humidity, $\%$, surface condition and anatomical directions.

Klašnja and Kopitović (1992) have shown that the temperature is a key factor in forming a watertight glue bond. According to Bradly and Kamke (1988) better glue spillage at higher temperatures, due to the reduction of viscosity, results in better penetration of glue into the wood. They found that the variability of the anatomical structure of wood is the most influential factor for glue penetration.

Reduction of shear strength after the cyclic cooking for both process of gluing was nearly equal, about $35 \%$. A better shear strength of HF glued specimens is not statistically significant. In the process of HF gluing, the glue heats up faster, resulting in a rapid reduction of viscosity. In this case the glue hardens quicker and penetrates slower into the wood (Resnik et al., 1997). The distribution of moisture content and temperature across the section is balanced, giving a bond without significant residual stresses.

On the other hand, in the case of conventional hot gluing, the heat and moisture move from the outer layers toward the centre. Less time is required to heat the middle layers than the external layers, due to slower transfer of heat by conduction. Different temperature gradient creates substantial moisture gradient over the intersection of elements, and higher humidity in the middle layers.

Šernek (1999) has shown that by gluing beech veneer sheets $2.2 \mathrm{~mm}$ thick in three-layer plywood with a conventional hot and HF gluing using UF glue, the moisture of veneer had a significant impact on the depth of penetration of UF glue, as well as on the shear strength. He found that optimal moisture content for the conventional gluing is somewhere between 4.1 and $5.7 \%$, and for the HF gluing between 5.7 and $9.2 \%$.

The values of shear strength were about $3 \mathrm{~N} / \mathrm{mm}^{2}$ for both gluing procedures.

In our experiments relatively high shear strength of the glue bond was reached, most probably due to the thickness of the specimens.

Slightly higher strength of HF glued samples in our experiment was primarily a consequence of higher increase of temperature in HF heating, smaller thickness loss and smaller internal stresses, which are very important in the process of relaxation after gluing.

\section{CONCLUSIONS 4. ZAKLJUČCI}

The results of this experiment confirmed that the technological process of gluing affects the physical and mechanical properties of LVL. The conventional hot and HF gluing leads to different dynamics in heating the glue layer, and therefore the time of gluing, moisture and temperature gradients and residual stresses are all considerably different.

These differences affect the amount of the total deformation and the relationship between the elastic and plastic deformation, i.e. the loss of thickness. All these caused the difference in other physical and mechanical properties.

There was a significant difference $(\alpha=0.05)$ in the mean values of the following physical and mechanical properties of HF and conventionally glued specimens: loss of thickness, density, moisture and bending strength. The elastic modulus and shear strength showed no statistically significant differences. 


\section{REFERENCES}

\section{LITERATURA}

1. Armstrong, L. D., 1982: Mechanical properties of wood. Research. Melbourne, CSIRO Australia. Division for Forest Products: $82 \mathrm{pp}$.

2. Boyd, J. D.; Foster, R. C., 1975: Microfibrilis in primary and secondary wall growth develop trellis configuration. Can. J. Bot., 53: 2687-2701.

3. Bradly, D. E.; Kamke, F. A., 1988. Effect of hot-pressing parameters on resin penetration. Forest Production Journal, 38, 11/12:63-68.

4. Gorišek, Ž., 1987: Vpliv parjenja na fizikalne lastnosti bukovine. Les, 39, 7/8: 181-188.

5. Klašnja, B.; Kopitović, S., 1992: Lignin-phenol-formaldehyde resins as adhesives in the production of plywood. Holz als Roh- und Werkstoff. 50, 7-8: 282-285.

6. Lu, X.; Pizzi A., 1998: Curing conditions effects on the characteristics of thermosetting adhesives-bonded wood joint - Part 1: Substrate influence on TTT and CHT curing diagrams of wood adhesives. Holz als Roh-und Werkstoff, 56:339-346 http://dx.doi.org/10.1007/s001070050330.

7. Mešić, N., 1998: Furniri i furnirske i stolarske ploče. Sarajevo, 386 pp.

8. Nikolić, M.S., 1988: Furniri i slojevite ploče. Beograd, Građevinska knjiga: 414 pp.

9. Resnik, J.; Šega, B., 1994: Thickness loss during the hot pressing of 3-layerd wood boards made of fir lamellas vs. wood preparation and pressing parameters. In: The first international conference on the development of wood science/technology and forestry, Great Missenden.
10. Resnik, J.; Tesovnik, F., 1995: Thickness loss when gluing veneer sheets into boards in the hot press or by high frequency, Holz als Roh - und Werkstoff, 53: 113-115 http://dx.doi.org/10.1007/BF02716405.

11. Resnik, J.; Šernek, M.; Kamke, F. A., 1997: High-frequency heating of wood with moisture content gradient. Wood and fibre science 29, 3: 264-271.

12. Rowell, R. M., 1966: Chemical Modification of Wood for Improved Adhesion in Composites. Wood Adhesives, For. Prod. Soc., Madison, WI. P.56-60.

13. Scallan, A. M., 1974: The structure of the cell wall of wood-a consequence of anisotropic intermicrofibrillar bonding. Wood Science and Technology, 6: 266-271.

14. Šernek, M., 1999: Vpliv bistvenih dejavnikov na penetracijo in trdnost UF lepilnega spoja pri lepljenju bukovine. M.sc. Thesis. Ljubljana, Univerza v Ljubljani, BF, Oddelek za lesarstvo: 108 pp.

15. Šernek, M.; Resnik, J.; Kamke, F. A., 1999: Penetration of liquid urea-formaldehyde adhesive into beech wood. Wood and fibre science 31, 1:41-48.

\section{Corresponding address:}

\section{Assistant Professor MURČO OBUĆINA, Ph.D.}

University of Sarajevo

Mechanical Engineering Faculty

Vilsonovo šetalište 9

71000 Sarajevo

BOSNIA AND HERZEGOVINA 